\title{
PHYSICOCHEMICAL CARACTERISTICS OF UNRIPE APPLES
}

\author{
Diana Crucirescu',2, ORCID ID: 0000-0002-6612-9937 \\ ${ }^{1}$ Scientific-Practical Institute of Horticulture and Food Technologies, \\ 59, Vieru str., Codru, Chisinau, Republic of Moldova \\ 2 Technical University of Moldova, 168, Stefan cel Mare Bd., Chisinau, Republic of Moldova \\ ${ }^{*}$ Corresponding author: Diana Crucirescu: diana.crucirescu@saiem.utm.md
}

Received: 10. 12. 2021

Accepted: 11. 28. 2021

\begin{abstract}
Apple plays an important role in human health. The unripe apples, after physiological falls and the agricultural operation "regulation of the fruit load", are not used for food. The use of agricultural organic waste is a current problem. In the presented paper was approached the possibility of valorification on these unripe fruits to obtain natural products. Were studied the unripe apples of 4 varieties: Coredana, Golden Rezistent, Rewena and Reglindis. The fruits were harvested during development at $45^{\text {th }}, 58^{\text {th }}, 71^{\text {st }}, 84^{\text {th }}$ and $97^{\text {th }}$ days after the full bloom. It was determined physico-chemical indices in fruits extracts. During the ripening of fruits, the diameter and mass increased continuously, the moisture content does not change significantly, but the $\mathrm{pH}$ values of the apple pulp increased nonessential. Dry matter content and total sugar increased considerably as the fruits were growing. There are unexpected increases in dry matter around the $84^{\text {th }}$ day after the full bloom. The acidity decreased during the fruit development. Sensory evaluation was also effectuated. The results obtained provide informations regarding the optimal use of the unripe apple varieties researched in order to process and obtain different products (especially natural acidifiers).
\end{abstract}

Keywords: unripe apples, total sugar content, acidity content, dry matter content, humidity, pH, sensory evaluation.

Rezumat: Mărul joacă un rol important în sănătatea umană. Mere necoapte, obținute în urma căderilor fiziologice și a operațiunii agricole „reglarea încărcăturii de rod pe pom”, nu sunt valorificate în scop alimentar. Utilizarea deșeurilor organice agricole este o problemă actuală. În lucrarea prezentată este abordată posibilitatea valorificării acestor fructe pentru obținerea unor produse naturale. Au fost studiate fructele de mere imature de 4 soiuri: Coredana, Golden Rezistent, Rewena și Reglindis. Acestea au fost recoltate pe parcursul dezvoltării la 45, 58, 71, 84 și 97 zile de la fenofaza înflorirea deplină. În extractele acestoara au fost determinați indicii fizico-chimici. În timpul dezvoltării fructelor, diametrul și masa au crescut continuu, conținutul de umiditate nu se schimbă esențial, iar valorile $\mathrm{pH}$-ului pulpei de mere au crescut neesențial. Conţinutul de substanțe uscate și zahărul total au crescut considerabil odată cu creșterea fructelor. Se observă o creștere bruscă a substanțelor uscate în jurul zilei a 84-a de la înflorirea deplină. Aciditatea a scăzut pe parcursul dezvoltării fructelor. Deasemenea a fost 
efectuată evaluarea organoleptică. Rezultatele obținute oferă informații cu privire la modul de utilizare optimă a soiurilor de mere imature cercetate în vederea prelucrării și obținerii diferitor alimente (în special acidifianți naturali).

Cuvintele-cheie: mere imature, conținutul de acizi organici, conținutul de zahăr total, conținutul de substanțe uscate, umiditatea, $\mathrm{pH}$, evaluare organoleptică.

\section{Introduction}

Apple is rich in organic acids, sugars, minerals and other nutrients, which play an important role in human health and one of the most important elements in the diet. These are the most demanded fruit by the Moldovan population and are eaten both fresh and processed. Due to their technological characteristics, they are raw material with a considerable share in the food industry. Thus, from a chemical point of view, they contain on average: 84 - 93\% water, $0.3 \%$ ash, $8.30 \%$ reducing sugars, $1.60-4 \%$ sucrose, $0.90-1.70 \%$ cellulose, 0 , 50\% pentosan, $0.40 \%$ lignin, $0.20 \%$ free acids, $0.60 \%$ combined acids, $0.4 \%$ pectin. In ash: potassium, sodium, silicon, calcium, phosphoric acid, iron, magnesium, bromine, sulfur, manganese, cobalt, tannin. In the peel and in the spine: galotanic acid [1, 2]. The core contains: ethers, acids - formic, acetic, capronic, acetaldehyde, geraniol. Regardless of the variety we choose, apples have in common most of the nutrients. What differs, to a greater or lesser extent, is the sugar content, up to $16 \%$ in the case of sweeter apples [1, 3].

In the Republic of Moldova, apples are the third highest value product in the agricultural sector in terms of revenue, being a strategic product for the northern part of the republic, where the largest plantations are located. The total area of orchards in our country reaches about 57 thousand ha, being cultivated about 40 varieties of apples, and apple production is estimated at about 611 thousand tons per year (Figure 1) [4].

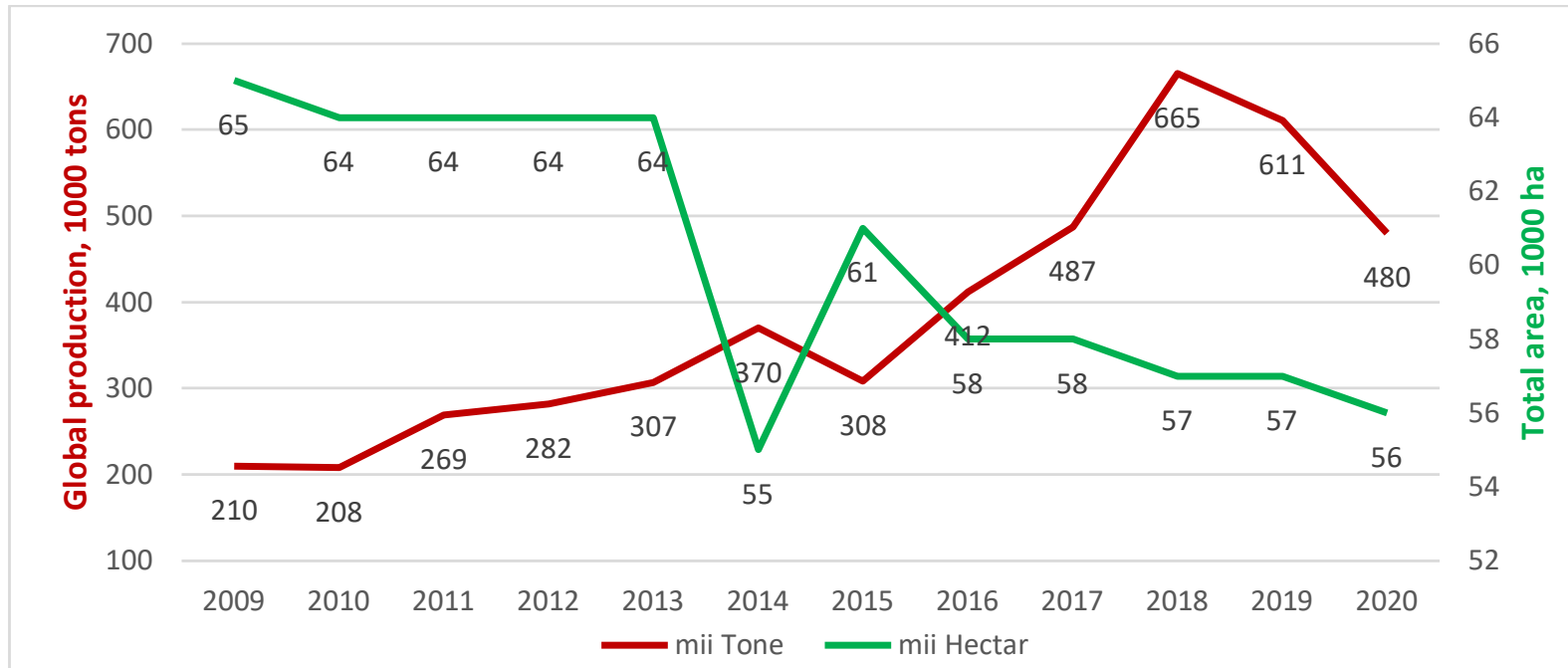

Figure 1. Evolution of apple plantations and harvest in the Republic of Moldova (years 2009-2019).

Source: taken from [4], processed by the author.

The sudden decrease of the plantation area in 2014 is due to the fact that the classic orchards were replaced with intensive ones and later with superintensive ones. The dry years leave a drastic mark on agriculture, affecting both the global production of apples and the 
trees in the orchards. One of these years was 2020 with the global production of 480 thousand tons and the total area of plantations 56 thousand hectares.

According to statistical data elaborated by Statista.com [5], the Republic of Moldova ranks $9^{\text {th }}$ in the world by the volume of apples exported (Figure 2).

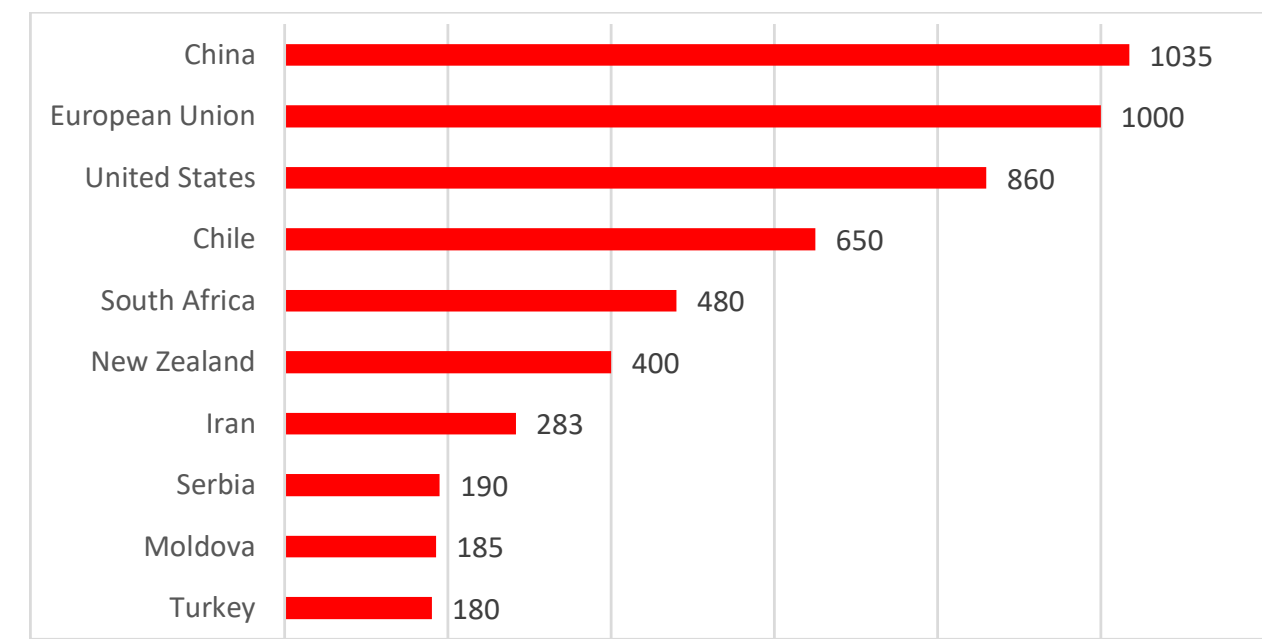

Figure 2. World leading countries in apple exports in the 2019/2020 marketing season, by volume exported in 1000 tons.

Source: taken from [5], processed by the author.

At the early phase of ripening apples, after physiological falls, the agricultural operation "regulation of the fruit load" takes place, after which about 25-30\% of the expected fruit is removed (especially in years with insufficient soil moisture) [3]. The significant amount of unripe fruit is not used for food, but is transformed into green mass as a fertilizer [6] or simply left on the ground as waste. Apple waste, following anaerobic fermentation, leads to harmful emissions, worsening soil and air quality, emitting unpleasant odors.

At the same time, not enough acidifiers of natural origin are known in the food industry. Monoacids of chemical / biochemical origin are mostly used [7, 8].

Significant volumes of apples in the early ripening phase, which are obtained by regulating the load of the harvest, as well as the need for natural acidifiers for use in the food industry, requires as a basic task the valorification of these apples and obtaining products with significant organic acids native and other valuable nutrients $[9,10]$.

The aim of this study was to evaluate the physicochemical indices in unripe apples to provide information on the optimal use of studied unripe apple varieties in order to process and obtain different foods (especially natural acidifiers).

\section{Materials and methods}

\section{Biological material}

Raw materials for the study served unripe apples, in the early ripening phase, of 4 varieties: Coredana, Golden Rezistent, Rewena și Reglindis. These were picked between June 5 and July 24, 2019 from the experimental lots of the Scientific-Practical Institute of Horticulture and Food Technologies, Chisinau, Republic of Moldova. The fruits were harvested during development at $45^{\text {th }}, 58^{\text {th }}, 71^{\text {st }}, 84^{\text {th }}$ and $97^{\text {th }}$ days after full bloom.

It was obtained extract from harvested apples by crushing and pressing. The yields of apple juices ranged from $30 \%$ to $50 \%$.

Determination of the quality indices of the unripe apples and them extracts 
The diameter of the samples of unripe apples was measured using the callipers. The mass of the samples was determined by using electronic balance. The moisture content was determined by drying in the oven at $103{ }^{\circ} \mathrm{C} \pm 2{ }^{\circ} \mathrm{C}$ for 3 hours. The experiment was repeated until the constant mass has been aceeved. The samples were cooled in the desiccator for one hour and weighed at the analytical balance [11].

To prepare the extracts, the washed apples were passed through a Slow screw extractor (Hotpoint, Ariston, Indesit Company). The juice obtained was centrifuged at 5000 rot $x$ min $^{-1}$ for 15 min. The filtration was then carried out through a cardboard filter with a diameter of $0,45 \mu \mathrm{m}$ of the holes. The collected filtrate served as a sample used to determine the titratable acidity, total sugar content, total soluble solids (dry counter), $\mathrm{pH}$ and sensory analysis. The clear juice was transferred to sealed bottles and stored at $-20^{\circ} \mathrm{C}$ until the analysis.

Content of dry metters (total solubile solids) was determined by electronic pocket refractometer ATAGO PAL-3 (Japan). The titratable acidity, content of total sugarand pH were determined using the methods described in ISO 750:1998 [12], by G. Bertrand and ISO 1842:1991 [13], respectively.

Standard ISO 6658: 2017 [14] was followed when performing the sensory analysis of the unripe apple extracts. Appearance, color, odor, taste, and overall acceptability were assessed using the 5-point system by an expert panel of eight trained food technologists. The panelists were between 35 and 75 years old. The 5-point assessment system includes the following scores: 5 - very good; 4 - good; 3 - satisfactory; 2 - poor; 1 - bad and 0 - very bad.

\section{Statistical analysis}

Variance analysis of the results was carried out by least square method with application of Microsoft Office Excel program. All analyses were performed in triplicate, with a maximum error of less than $5 \%$. Results obtained were expressed as average \pm SD.

General description of the apples variety used include:

COREDANA - variety obtained at Pomiculture Research Institute in the Republic of Moldova. The tree has a small to medium growth force, with a flattened spherical crown. It bears fruit early, the flowering season is medium. Trees are not demanding of the soil, they have high winter hardiness, medium at drought and heat resistance. The variety also has genetic resistance to scab and medium resistance to powdery mildew. The fruit is large in size with a mass of $170-250 \mathrm{~g}$, spherical shape, sometimes flattened. The covering color is red with streaks.The flesh is cream-white, fine, juicy, crunchy, with a sweet-sour taste. Harvest period: late August or early September. Productivity is $28-35$ t/ha. Apples are resistant to handling and transport. The fruits can be stored 120-130 days. The variety is approved for all fruit-growing areas of the country [1,3].

GOLDEN REZISTENT - variety obtained in SUA. The tree has a medium growth force, with a large-pyramidal and dense crown. It bears fruit early, the flowering season is medium. Trees are not demanding of the soil, they have high winter hardiness, medium resistance to powdery mildew and scab. Apple is medium to large in size, with a mass of 150-160 g. It has a conical-oblong to conical-truncated shape and a smooth surface. The covering color is yellow, but sun-exposed fruits may be covered with an orange blush. Harvest period: the $3^{\text {rd }}$ decade of September - early October. Productivity is 30-40 t/ha. The fruits can be stored 180210 days and are eaten mostly fresh. The variety is authorized for all areas of the republic [1, 3]. 
REGLINDIS - variety obtained in Germany. The tree has a medium to weak vigor, with a globular crown. It bears fruit early, the flowering season is medium. The trees are demanding to the soil, have medium winter hardiness. It has genetic resistance to scab and high resistance to powdery mildew. The fruit is of medium to large size, a mass of 170-200 $\mathrm{g}$, with a globular or conical-globular shape. The covering color is red with streaks and occupies about $75 \%$ of the surface of the fruit. The flesh is fine, crunchy, white-cream, juicy, with a very good taste. Harvest period: the $2^{\text {nd }}$ decade of September. Productivity is 30-35 t/ha. Apples are resistant to handling and transport. The fruits can be stored 90-115 days days and are eaten mostly fresh $[1,3]$.

REWENA - new resistant variety obtained in Germany. it is considered one of the best varieties of apples in the world. The tree has a medium vigor, with a globular crown. It bears fruit early, the flowering season is medium. The trees are demanding to the soil, have high winter hardiness. It has stable scab resistance and high resistance to powdery mildew. . The fruit is of medium to large size, a mass of $160-230 \mathrm{~g}$, with a globular or conical-globular shape. The covering color is yellow with a light red blush that occupies about $70-90 \%$ of the fruit's surface. The flesh is fine, crunchy, white-cream, juicy and fragrant; with a sweet-sour taste. Harvest period: the $3^{\text {rd }}$ decade of September - early October. Productivity is 30-35 t/ha. The fruits can be stored 90-115 days days and are eaten mostly fresh [1, 3].

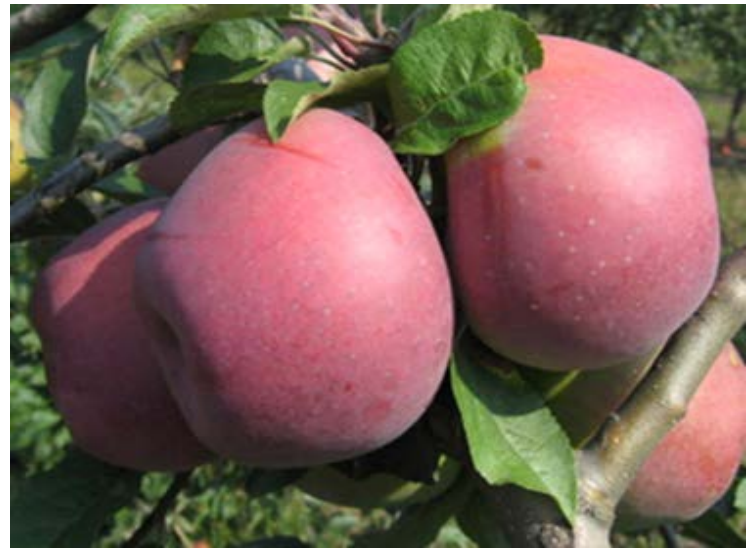

a)

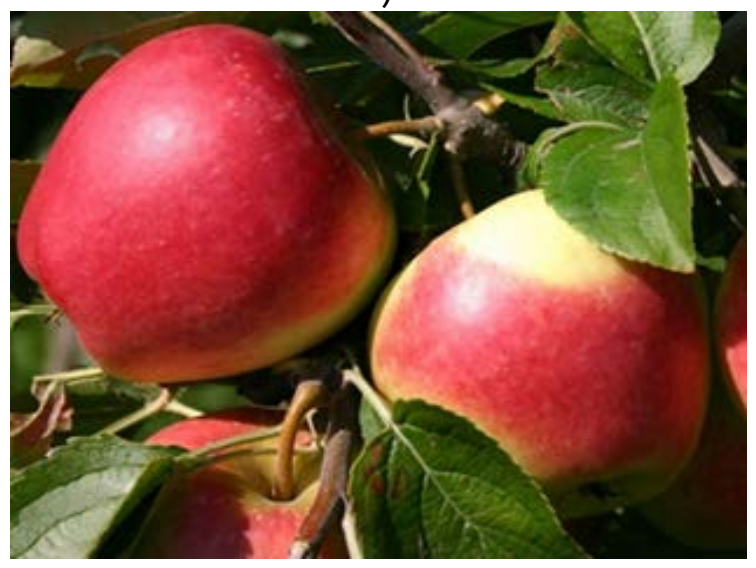

c)

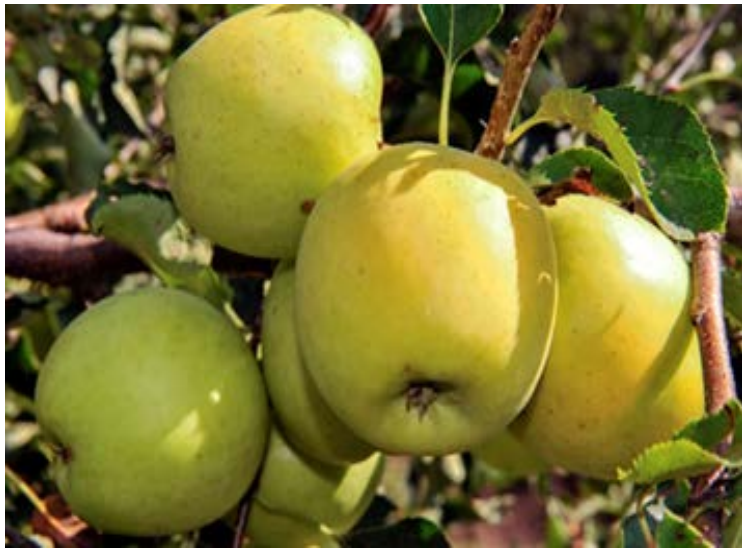

b)

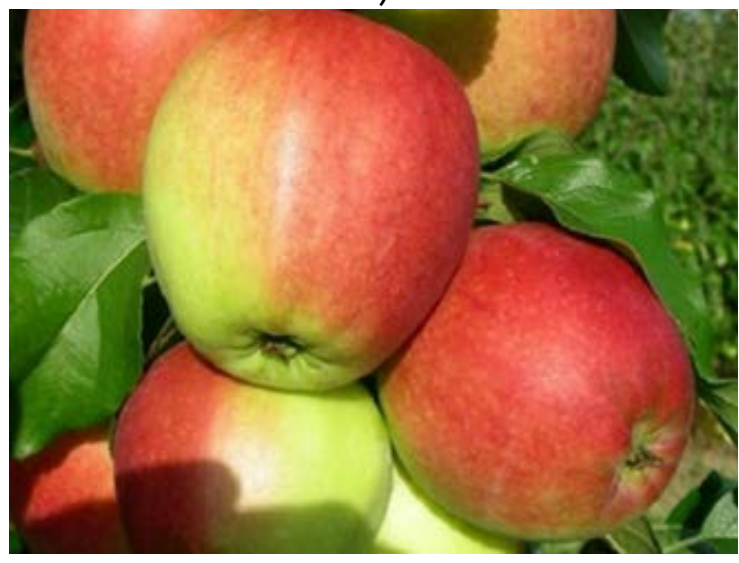

d)

Figure 3. Image of apple fruits of the varieties Coredana (a), Golden Delicios (b), Reglindis (c), Rewena (d).

Source: taken from $[1,3]$. 


\section{Results and discussions}

Between June 1 and July 24, 2019, unripe apples and their extracts were analyzed. Subsequently, samples of acidifiers were obtained from these apples in laboratory conditions. As a raw materials were used unripe apples, in the early ripening phase, of 4 varieties: Coredana, Golden Rezistent, Rewena și Reglindis.

As expected, the diameter and mass of the fruit during growth increased continuously for all the apple varieties analyzed [15, 16]. During the ripening process of apple fruits, various physiological changes take place (the process of photosynthesis).

Fruit development has 2 phases. The first stage starts from with blooming and lasts about 35 days, during which the exponential cell division takes place (the first 7 days) and the increase of the fruit mass due to the division and expansion of the cells (from the $7^{\text {th }}$ to about the $35^{\text {th }}$ day) [17]. The second phase of growth begins before the end of cell division and lasts until the fruits are harvested. Finally, growth for the rest of the season occurs mainly only by expanding the cells. During this period the fruit adds a similar amount of weight each day $[16,17]$.

The dynamics of the mass and diameter of the studied unripe apple fruits are presented in figure 4.

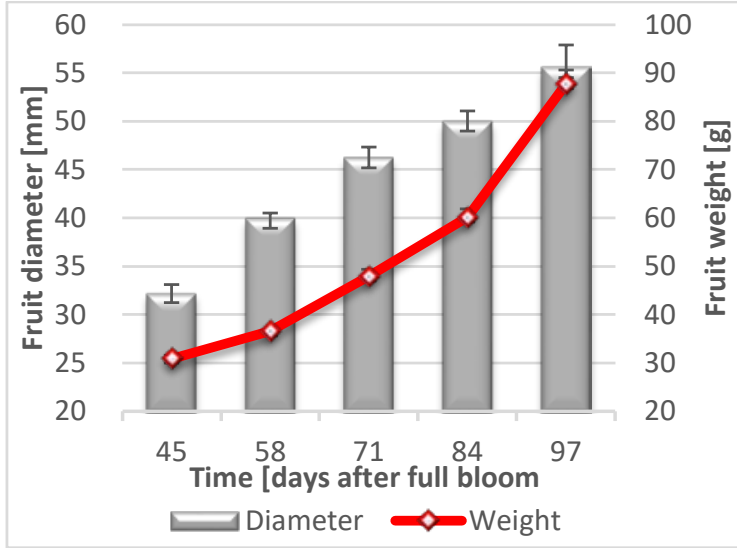

a)

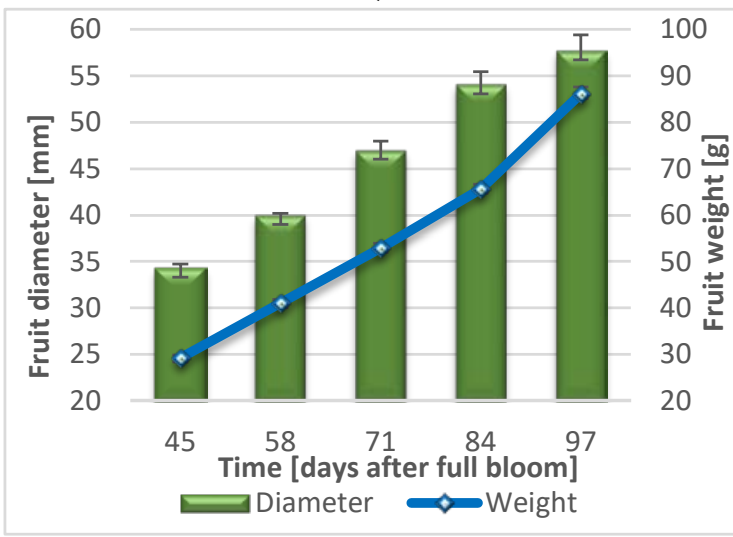

c)

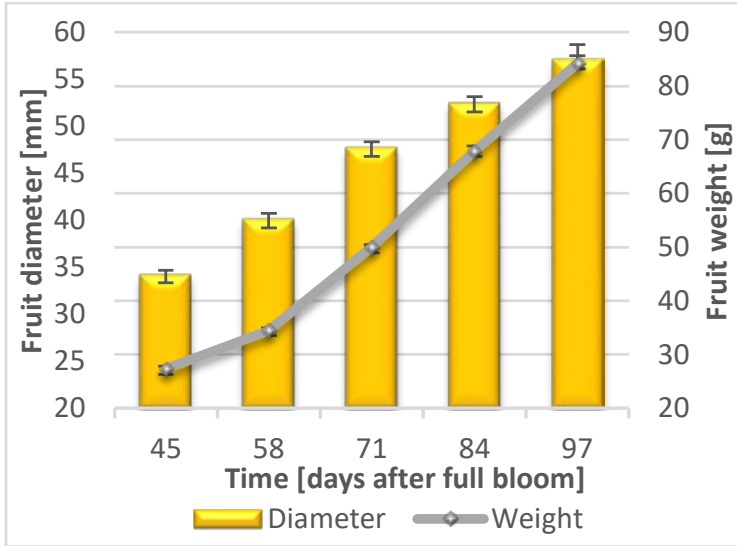

b)

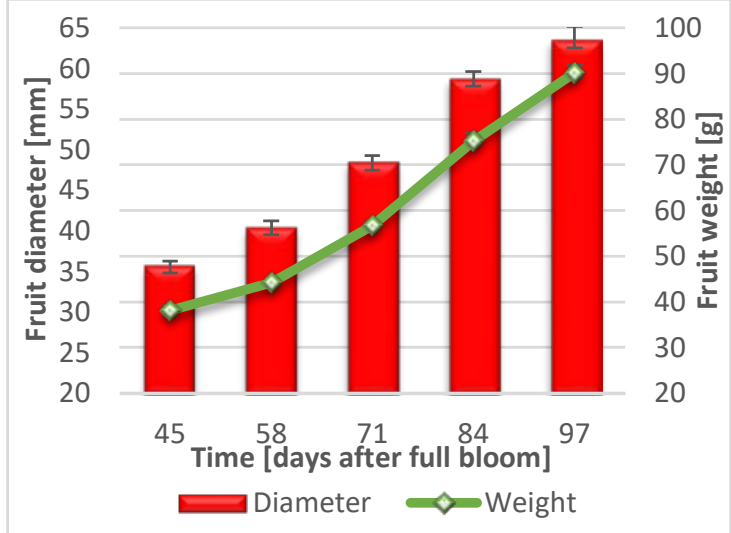

d)

Figure 4. Dynamics of mass and diameter during the development of apple fruits of the varieties Coredana (a), Golden Delicios (b), Reglindis (c), Rewena (d).

Source: authored.

A preventive analysis of unripe apples in order to obtaining natural acidifiers was effectuate in 2016 [18]. That study has shown that unripe apple fruit is a source of valuable nutrients and native organic acids. 
In this research the physico-chemical indices of apples and their extracts were studied at $45^{\text {th }}, 58^{\text {th }}, 71^{\text {st }}, 84^{\text {th }}$ and $97^{\text {th }}$ days after the full bloom phenophase. That are presented in Table 1.

Table 1

\section{Physico-chemical indices of fruits of four apple varieties and extracts} from these during their development (average \pm SD).

\begin{tabular}{|c|c|c|c|c|c|c|}
\hline Variety & $\begin{array}{l}\text { Days } \\
\text { AFB }^{*}\end{array}$ & Moisture, \% & Acidity $^{* *}, \%$ & $\begin{array}{c}\text { Dry metter, } \\
\text { ('Brix) }\end{array}$ & $\begin{array}{c}\text { Total sugar, } \\
\% \\
\end{array}$ & $\mathrm{pH}$ \\
\hline \multirow{5}{*}{ 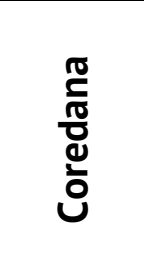 } & 45 & $85,30 \pm 0,95$ & $1,83 \pm 0,023$ & $6,5 \pm 0,01$ & $3,87 \pm 0,04$ & $3,02 \pm 0,021$ \\
\hline & 58 & $86,45 \pm 0,83$ & $1,75 \pm 0,017$ & $7,7 \pm 0,02$ & $5,20 \pm 0,02$ & $3,18 \pm 0,002$ \\
\hline & 71 & $84,91 \pm 0,70$ & $1,60 \pm 0,005$ & $8,7 \pm 0,01$ & $6,33 \pm 0,03$ & $3,09 \pm 0,003$ \\
\hline & 84 & $85,30 \pm 0,72$ & $1,54 \pm 0,003$ & $10,8 \pm 0,00$ & $9,08 \pm 0,01$ & $3,06 \pm 0,008$ \\
\hline & 97 & $83,60 \pm 0,24$ & $1,20 \pm 0,004$ & $12,8 \pm 0,01$ & $11,18 \pm 0,01$ & $3,13 \pm 0,001$ \\
\hline \multirow{5}{*}{ 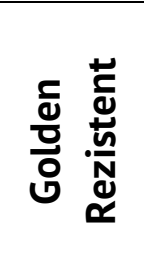 } & 45 & $87,23 \pm 0,53$ & $2,20 \pm 0,000$ & $7,6 \pm 0,01$ & $4,65 \pm 0,01$ & $2,78 \pm 0,003$ \\
\hline & 58 & $86,67 \pm 0,07$ & $2,09 \pm 0,013$ & $8,1 \pm 0,02$ & $5,21 \pm 0,02$ & $2,90 \pm 0,004$ \\
\hline & 71 & $86,29 \pm 0,23$ & $1,82 \pm 0,014$ & $9,2 \pm 0,01$ & $7,13 \pm 0,01$ & $2,95 \pm 0,001$ \\
\hline & 84 & $87,82 \pm 0,02$ & $1,77 \pm 0,002$ & $11,0 \pm 0,01$ & $8,73 \pm 0,04$ & $3,03 \pm 0,001$ \\
\hline & 97 & $86,51 \pm 0,32$ & $1,50 \pm 0,003$ & $12,7 \pm 0,00$ & $10,30 \pm 0,05$ & $3,12 \pm 0,000$ \\
\hline \multirow{5}{*}{ 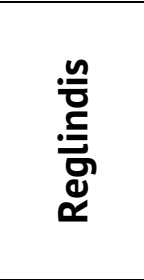 } & 45 & $84,60 \pm 0,08$ & $2,60 \pm 0,012$ & $6,3 \pm 0,00$ & $3,73 \pm 0,03$ & $3,02 \pm 0,007$ \\
\hline & 58 & $83,20 \pm 0,73$ & $2,40 \pm 0,007$ & $7,6 \pm 0,14$ & $5,26 \pm 0,04$ & $3,16 \pm 0,004$ \\
\hline & 71 & $84,30 \pm 0,91$ & $2,35 \pm 0,012$ & $8,4 \pm 0,05$ & $5,28 \pm 0,02$ & $3,00 \pm 0,003$ \\
\hline & 84 & $84,50 \pm 0,72$ & $2,07 \pm 0,006$ & $10,4 \pm 0,02$ & $7,33 \pm 0,02$ & $3,27 \pm 0,002$ \\
\hline & 97 & $83,90 \pm 0,09$ & $1,90 \pm 0,018$ & $11,9 \pm 0,01$ & $9,28 \pm 0,01$ & $3,45 \pm 0,003$ \\
\hline \multirow{5}{*}{ 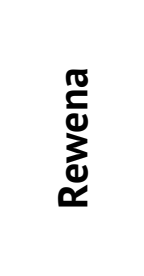 } & 45 & $86,70 \pm 0,07$ & $2,95 \pm 0,012$ & $6,7 \pm 0,03$ & $3,45 \pm 0,08$ & $2,20 \pm 0,001$ \\
\hline & 58 & $86,30 \pm 0,20$ & $2,87 \pm 0,007$ & $7,8 \pm 0,01$ & $4,53 \pm 0,01$ & $2,43 \pm 0,002$ \\
\hline & 71 & $87,05 \pm 0,40$ & $2,75 \pm 0,001$ & $8,3 \pm 0,03$ & $5,37 \pm 0,02$ & $2,70 \pm 0,000$ \\
\hline & 84 & $86,90 \pm 0,08$ & $2,60 \pm 0,001$ & $10,5 \pm 0,00$ & $7,11 \pm 0,05$ & $2,77 \pm 0,021$ \\
\hline & 97 & $86,50 \pm 0,07$ & $2,24 \pm 0,002$ & $12,0 \pm 0,01$ & $9,68 \pm 0,04$ & $2,94 \pm 0,020$ \\
\hline
\end{tabular}

* Days AFB - days after the full bloom

** Titratable acidity, expressed in malic acid

During the growth and development of apple fruits, the moisture content does not change significantly, the values being between $83.20 \%$ and $87.82 \%$ for all 4 varieties studied.

The dry matter content increased considerably with the growth and development of the apple fruit, with values between $6.5^{\circ}$ Brix and $12.8^{\circ}$ Brix for the Coredana variety, between $7.6^{\circ} \mathrm{Brix}$ and $12.7^{\circ} \mathrm{Brix}$ for the Golden Resistant variety, between $6.3^{\circ} \mathrm{Brix}$ and $11.9^{\circ} \mathrm{Brix}$ for the Reglindis variety and between $6.7^{\circ} \mathrm{Brix}$ and $12.0^{\circ} \mathrm{Brix}$ for the Rewena variety. The highest values of this index were recorded for the Coredana and Golden Rezistent varieties, followed by the Rewena and Reglindis varieties. There are unexpected increases in dry matter around the $84^{\text {th }}$ day after the full bloom, followed by a slow increase.

The total amount of carbohydrates increases significantly during fruit development, registering values between $3.87 \%$ and $11.18 \%$ for the Coredana variety, between $4.65 \%$ and $10.3 \%$ for the Golden Resistant variety, between $3.73 \%$ and $9.28 \%$ for the Reglindis variety and between $3.45 \%$ and $9.68 \%$ for the Rewena variety. Ma și colab. (2015) in his study they showed that fructose and sucrose were the main components of soluble sugars in cultivated 
fruits, while fructose and glucose were the main elements of sugars in wild fruits [19]. The increase of dry matter content and total sugar is due to the hydrolysis of the starch contained in immature apples. In their study, Bart et al. (2008) and Mureșan et al. (2015) have demonstrated that starch accumulation occurs between the $35^{\text {th }}$ and $84^{\text {th }}$ days after full flowering, reaching its maximum value around the $84^{\text {th }}$ day $[20,21]$.

The acidity decreased during fruit growth. Thus, values between $1.83 \%$ and $1.20 \%$ were registered for the Coredana variety, between $2.20 \%$ and $1.50 \%$ for the Golden Resistant variety, between $2.60 \%$ and $1.90 \%$ for the Reglindis variety and between $2.95 \%$ and $2.24 \%$ for the Rewena variety. The highest acidity was recorded for the Rewena variety, followed by the Reglindis, Golden Rezistent and Coredana varieties. The malic acid takes up about $90 \%$ of the total content of organic acids [22]. The acidity content decreases slightly during ripening. This could be due to the degradation of citric acid, the transformation of acids during respiration, their conversion into sugars and their subsequent use in the metabolic process in the fruit $[16,23,24]$. At the same time, the processes involved in the metabolism and accumulation of malic and citric acid in mesocarp cells are under both genetic and environmental control. [25]. Many agronomic studies have shown the impact of cultural practices, including irrigation, mineral fertilization, temperature, thinning [26, 27, 28].

The $\mathrm{pH}$ values of the apple pulp do not change significantly. They increase slightly from 3.02 to 3.13 for the Coredana variety, from 2.78 to 3.12 for the Golden Resistant variety, from 3.02 to 3.45 for Reglindis and from 2.20 to 2.94 for Rewena. Zheng et al. (2012) reported similar results for Fuji variety [29].

Metabolic changes in sugars and organic acids in fruits play an important role in fruit yield and quality. These determine the organoleptic characteristics of the fruit. Soluble sugars determine the sweetness of apple fruits, and organic acids are responsible for acidity. These obvious transformations of the fruit, which exist in the ripening phase, are perceived both through the human senses and through the laboratory apparatus. Much more complete is the index derived from the sugar / acidity ratio (TSS / AT), which is more strictly related to the quality of the fruit in relation to the unique values of TSS and AT. However, the relationship can vary from year to year [30].

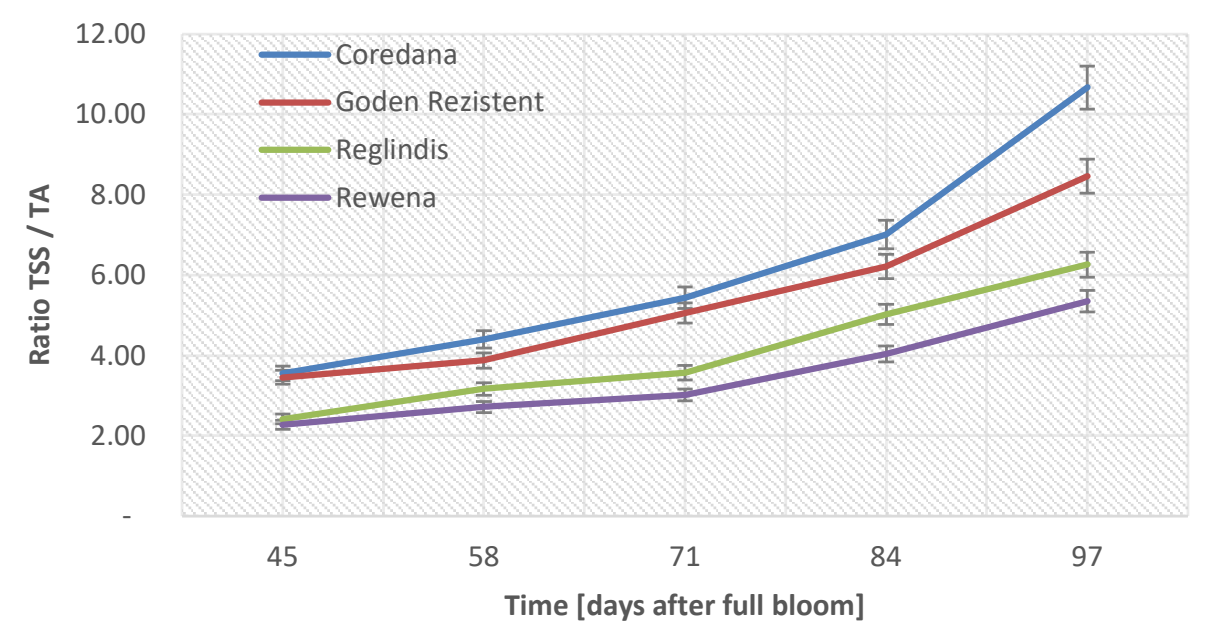

Figure 5. Dynamics of ratio TSS/TA during the development of apple fruits of the varieties Coredana, Golden Delicios, Reglindis, Rewena.

Source: authored. 
This index serves as an industrial indicator, because the balance between sugars and organic acids influences the taste of the beverage [22]. Sugar / acidity indices of ripe apple varieties Idared and Crips Pink, studied by Bandić et al. (2019), were 28 and 35, respectively. Alberti et al. (2016) demonstrated in his paper that unripe apple fruits showed a ratio of less than 20, which is suitable for industrial processing [31].

Based on the determined values of the total carbohydrate content and the titratable acidity, the TSS / TA indices were calculated for all 4 varieties of apples studied in the given paper and were presented in figure 5.

The results obtained for the 4 apple varieties demonstrate that, in order to obtain the acidifiers, the unripe apples must contain dry metter substances with values between $6.3^{\circ}$ Brix to $12.8^{\circ}$ Brix. In this phase they accumulate carbohydrates $3.45 \%-11.18 \%$, have a titratable acidity from $1.20 \%$ to $2.95 \%$ (expressed in malic acid) and $\mathrm{pH}$ values from 2.20 to 3.45 , and the sugar / acidity index will be between values 2.27 and 10.67 .

Sensory evaluation of unripe apple extracts was also effectuated. Currently, instrumental sensory analyzers are widely used. However, some researchers insist on organoleptic evaluation by a group of experts consisting of trained food technologists [32, 33].

The studied extracts were sensorially analyzed by 8 evaluators, using a 0-5 - point rating system. Each evaluator recorded the results in their own sensory evaluation sheet. $A$ score value from 0 to 5 was given for each sensorial characteristic. The average scores were computed based on the results. The results are shown in Figure 6.
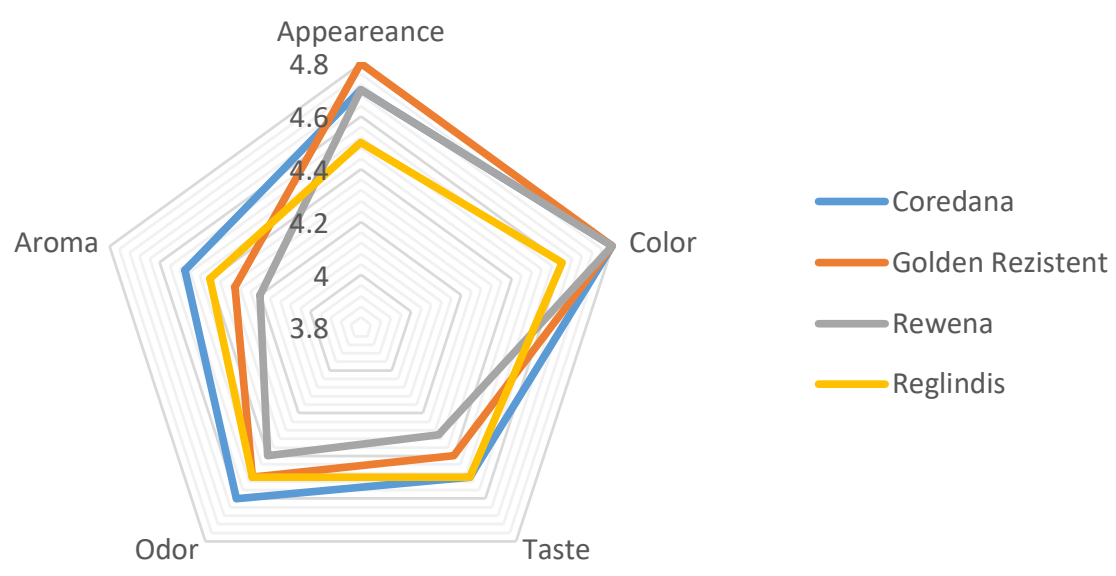

Rewena

Reglindis

Figure 6. Spider diagram of organoleptic characteristics in unripe apple extracts of 4 varieties Coredana, Golden Delicios, Reglindis, Rewena.

Source: authored.

According to the descriptive evaluation, it was found that the studied samples show relatively clear juice (depending on the method of obtaining). The color was from yellowstraw to light-brown. The taste is intensely acidic and pleasant, slightly sweet, pleasant, specific to the variety, without foreign taste and odor. The aroma was pleasant, specific to unripe apple, expressed moderately, characteristic of apple varieties. 


\section{Conclusions}

The unripe apple fruits of 4 varieties were studied: Coredana, Golden Rezistent, Rewena and Reglindis. The fruits were harvested during ripening period at $45^{\text {th }}, 58^{\text {th }}, 71^{\text {st }}, 84^{\text {th }}$ and $97^{\text {th }}$ days after the full bloom phenophase.

The diameter and mass of the fruits during development have continuously increased for all the analyzed apple varieties. Mosture content $(83.20 \%-87.82 \%)$ and $\mathrm{pH}(2.78-3.45)$ values does not change significantly for all 4 varieties studied. The dry matter content has increased considerably and highest values of this index were $11.9-12.8^{\circ}$ Brix. There are unexpected increases in dry matter around the $84^{\text {th }}$ day after the full bloom. The acidity decreased during the fruit development. The highest values were recorded for the Rewena variety with values between $1.83 \%$ and $1.20 \%$, followed by the Reglindis variety $(2.95 \%$ and 2.24\%), Golden Rezistent (2.60\% and $1.90 \%$ ) and Coredana (2.20\% and $1.50 \%)$. The total sugar content increases significantly during fruit development, registering values between $3.87 \%$ and $11.18 \%$ for the Coredana variety, between $4.65 \%$ and $10.3 \%$ for the Golden Resistant variety, between $3.73 \%$ and $9.28 \%$ for the Reglindis variety and between $3.45 \%$ and $9.68 \%$ for the Rewena variety. The sugar / acidity index will be between values 2.27 and 10.67 .

The results of this study indicate that provide informations regarding the optimal use of the unripe apple varieties studied in order to process and obtain different products (especially natural acidifiers). The products obtained will contain organic acids and valuable nutrients. They can be used as a source of acidity in the food industry (manufacture of juices, beverages, preserves), substituting acidifiers of chemical origin and improving the nutritional value of food.

At the same time, the recovery of unripe apples, obtained by regulating the fruit load on the tree or following physiological falls, will contribute to increasing sustainability through the efficient use of vegetale agricultural waste, using it as a raw material.

\section{Bibliografia}

1. Bucarciuc V. Perspective apple varieties. Chișinău, "Bons Offices" Publishing House, 2015, 264 p. [In Romanian]

2. Muste S. Vegetable raw materials in the Food Industry (reissue edition 2008). Cluj-Napoca, "Academicpres" Publishing House, 2010, 172 p. [In Romanian]

3. Babuc V., Peșteanu A., Gudumac E., Cumpanici A. Apple production. Chișinău, "Bons Offices" Publishing House, 2013, 240 p. [In Romanian]

4. National Bureau of Statistics of the Republic of Moldova. Statistics by fields - Agriculture - Plant culture Multiannual plantations by crops and categories of households, 1980-2019 [online, accessed 20.11.2020]. Available: http://www.statistica.md/category.php?l=ro\&idc=127\& [In Romanian]

5. Statista.com [online, accessed 20.12.2020]. Available: https://www.statista.com/statistics/756433/globaltop-apple-exporter-worldwide/

6. Peșteanu A., Calestru O. Adjusting the fruit load on Golden Reinders apple trees by various thinning methods. In: Ştiinţa agricolă, 2018, 2, pp. 37-42.

7. Tatarov P. Food Chemistry. Chisinau, “MS Logo" Publishing House, 2017, 450 p. [In Romanian]

8. Banu C., Stoica A., Bărăscu E. et al. Applications of additives and ingredients in the food industry. Bucharest, "ASAB" Publishing House, 2010, 877 p. [In Romanian]

9. Golubi R., Iorga E., Bucarciuc V., Arnăut S., Crucirescu D. Processes for producing an acidifier from apples. Patent no. 1286 BOPI, 2018-10-31. [In Romanian]

10. Crucirescu D. Rational use of unripe apples. In: Technical University of Moldova. The technical scientific conference of undergraduate, master and PhD students. (Chisinau, 1-3 april, 2020), Chişinau: Tehnica-UTM, 2020, v. 1, pp. 401-404. [In Romanian]

11. AOAC, 1999, Official methods of analysis. $16^{\text {th }}$ ed. $5^{\text {th }}$ revision. Volume II. Chapter 44. Subchapter 4. Cunnif, P. (ed.) AOAC International, Washington, D.C., USA. 
12.SM SR ISO 750:2014 Fruit and vegetable products. Determination of titratable acidity. [In Romanian]

13. ISO 1842:1991 Fruit and vegetable products. Determination of $\mathrm{pH}$.

14.ISO 6658:2017. Sensory Analysis. Methodology. General Guidance; International Organization for Standardization: Geneva, Switzerland, 2017

15. Mureșan A. E., Mureșan V. Accumulation, transformation and characterization of biochemical compounds in apple fruits. Cluj-Napoca, "MEGA" Publishing House, 2019, 98 p. [In Romanian]

16. Rosnah S., Wong W. K., Noraziah M., Osman H. Chemical composition changes of two water apple (Syzygium samaragense). In: International Food Research Journal, 2012, 19 (1), pp. 167-174.

17. Lasko A. N. and Goffinet M. C. Apple Fruit Growth. In: New York fruit quarterly, 2013, 21, 1, pp. 11-14.

18. Crucirescu D. Unripe apples - raw material for obtaining the natural acidifier. In: Technical University of Moldova. The technical scientific conference of undergraduate, master and PhD students. (Chisinau, 26-29 martie, 2019), Chişinau: Tehnica-UTM, 2019, v. 1, pp. 505-508. [In Romanian]

19. Ma B.Q., Chen J., Zheng H.Y. et al. Comparative assessment of the composition of sugar and malic acid in cultivated and wild apples. Food Chemistry, 172 (2015), pp. 86-91

20. Bart J. J., Thodey K., Schaffer R. J. et al. Global gene expression analysis of apple fruit development from the floral bud to ripe fruit. In: BMC Plant Biology, 2008, 8 (16), pp. 1-29.

21. Mureșan E. A., Muste S., Vlaic R. A. et al. The Dynamics of Starch and Total Sugars during Fruit Development for Ionathan, Starkrimson and Golden Delicious Apple. In.: Bulletin UASVM Food Science and Technology, 2015, 72(1), pp. 120-126. [In Romanian]

22. Bandic L. M., Žulj M. M., Fruk G. et al. The profile of organic acids and polyphenols in apple wines fermented with different yeast strains. In: Journal of Food Science and Technology, 2019, 56(2), pp. 599-606.

23. Ackermann J., Fischer M. and Amad Ó. R. Changes in sugars, acids, and amino acids during ripening and storage of apples (Cv. Glockenapfel). In: Journal of Agricultural and Food Chemistry, 1992, 40, pp. 1131-1134.

24. Bizjak J., Mikulic-Petkovsek M., Stampar F. and Veberic R. Changes in Primary Metabolites and Polyphenols in the Peel of "Braeburn" Apples (Malus domestica Borkh.) during Advanced Maturation. In: Journal of Agricultural and Food Chemistry, 2013, 61(43), pp. 10283-10292.

25. Etienne A., Genard M., Lobit P., Mbeguie-A-MbeguiE D. and Bugaud C. What controls fleshy fruit acidity? A review of malate and citrate accumulation in fruit cells. In: J. Exp. Bot. 2013, 64, pp. 1451-1469.

26. Thakur A. and Singh Z. Responses of 'Spring Bright' and 'Summer Bright' nectarines to deficit irrigation: fruit growth and concentration of sugars and organic acids. In: Scientia Horticulturae, 2012, 135, pp. 112-119.

27.Wu B.H., Genard M., Lescourret F. et al. Influence of assimilate and water supply on seasonal variation of acids in peach (cv Suncrest). In: Journal of the Science of Food and Agriculture, 2002, 82, pp. 1829-1836.

28. Burdon J., Lallu N., Yearsley C. et al. Postharvest conditioning of Satsuma mandarins for reduction of acidity and skin puffiness. In: Postharvest Biology and Technology, 2007, 43, pp. 102-114.

29.Zheng H.Z., Kim Y.I. and Chung S.K. A profile of physicochemical and antioxidant changes during fruit growth for the utilisation of unripe apples. In: Food Chemistry, 2012, 131, pp. 106-110.

30. Campisi D. Use of chemical physical analysis and sensory for qualitative assessment of apple fruits, nespolo from Japan, lyes and mango grown in Sicily. PhD thesis. 2013

31. Alberti A., dos Santos T.P.M., Zielinski A.A.F. et al. Impact on chemical profile in apple juice and cider made from unripe, ripe and senescent dessert varieties. In: Food Sci Technol-LEB, 2016, 65, pp. 436-443.

32. Tanaka F., Hayakawa F. and Tatsuki M. Flavor and Texture Characteristics of 'Fuji' and Related Apple (Malus domestica L.) Cultivars, Focusing on the Rich Watercore. In: Molecules, 2020, 25(5), 1114.

33. Deng H., Zhao P.T., Yang T.G., Meng Y.H. A comparative study of the cloudy apple juice sterilized by hightemperature short-time or high hydrostatic pressure processing: shelf-life, phytochemical and microbial view. In: Food Science and Technology, 2021, 63620. 